DOI https://doi.org/10.36059/978-966-397-108-7/205-227

\title{
ETHNIC PROCESSES IN UKRAINE IN THE CONTEXT OF STALIN REPRESSIONS
}

\section{Chirko B.}

\section{INTRODUCTION}

Repressions of Stalin totalitarian regime concerning the German ethnic group in Ukraine in the 1920th - the 1930th found significant reflection in works of the Ukrainian and foreign researchers. The specified problems are investigated in scientific works of V.V. Chentsova, M.M. Shityuk, M.I. Panchuka, V.B. Evtukh, A.S. Rublyov, V.M. Nikolsky, A.I. Savin, Alfred Aysfeld and also other researchers of the history of the German ethnic minority in Ukraine. The author of the offered publication continues researches of features of the position of ethnic Germans of Ukraine in the context of repressive actions of the Stalin mode.

\section{Socio-political interests of Soviet party structures and intelligence agencies of the mode of the German "fifth column" in the USSR}

In the late 1920-s the Stalin totalitarian regime was finally formed in the USSR. The fundamental changes took place in the field of national policy. Ukrainianization seemed to be fold and a state policy on national minorities was changed too. It's important that chauvinistic tendencies should be intensified in the republic after appointment of the protagonists of J. Stalin - P. Postisheva, M. Popov, V. Balitsky to work in Ukraine. It was the period (1933-1934) when a new wave of antiUkrainian campaign was begun - the "revelation" of Ukrainian "nationalism" (in particular, the so-called "Skrypnyk area"). Along with allegations of Ukrainian "nationalism" there were declared statements about "fascists" from the national minorities. In the resolution of November (1933) to the joint Plenum of the Central Committee and the Central Committee of the CP (b) U "Results an the immediate tasks of national politics in Ukraine" in the section "Work among national minorities" it was noted: "... The weakening of the Bolshevik vigilance of party organizations in work among the working people of national 
minorities, especially among the Polish and German people which led to the clogging of collective farms, schools, clubs, institutes, etc. Polish and German fascist elements, some of which even fled to the party"1.

The Plenum of the Central Committee and the Central Committee of the CP (b) U has demanded the adoption of appropriate measures to combat "nationalists" and "hostile elements".

It must be said that the search for "nationalists" and "fascists", as well as general repressive actions against "enemies of the people" (including those of the national minorities), were closely connected with the administrative and prescriptive methods of implementing domestic policy, militarization of the economy, collectivization of the village, forced grain procurement, anti-religious campaigns, etc. Repressions against "nationalists" (German, Polish, and others) were also defined by an international factor as the aggravation of the situation in the world. The deterioration of relations between the USSR and Germany and Poland and the corresponding intensification of the anti-German and anti-Polish propaganda campaigns led in particular to the special bias of the Soviet authorities against the German and Polish populations. It was considered as a potential basis for "fascist" activities in the country.

It should be mentioned that targeted advocacy campaigns and repressive actions of the punitive bodies of the regime according to ethnic Germans in the USSR took place in the early 1930-s. This fact was covered in the publications of Dr. V. Hodeler and researcher of the history of the Germans of the USSR, Andrew Savin. In studying recent archival documents A. Savin concludes that before the arrival of Nazis in Germany and the emergence of military danger the leadership of the Soviet intelligence agencies began to formulate the concept of the German iaspora as "a spy and sabotage base" in the USSR ${ }^{2}$ A. Savin proves new approaches to the history of the emergence and an intensification of the anti-German campaigns in the USSR based on the archival documents published by the author in work "Ethnic confession in Soviet the state. Mennonites of Siberia in the 1920-1930th years: emigration and

\footnotetext{
1 Партробітник України. Орган Центрального комітету та Харківського обласного Комітету Комуністичної партії (більшовиків) України. - 1933. - № 16. - С. 35.

2 Этноконфессия в советском государстве. Меннониты Сибири в 1920-1930-е годы: эмиграция и репрессии. Документы и материалы / [составитель и научный редактор А. И. Савин] / Андрей Іванович Савин. - Новосибирск: «Посох», 2009. - С. 215-217.
} 
repressions. Documents and materials" (Novosibirsk, 2009) ${ }^{3}$. First of all documents mean: The circular letter of OGPU USSR No. 7/37 "On the German intelligence and fight against it" (on July 9, 1924) and the Reference of KRO OGPU "The German Counter-revolutionary Work in the USSR" (no later than July 14, 1925.).

Analyzing the specified documents we will pay attention to a special nature of the relations between Soviet Russia and Germany which developed in the early twenties. On May 6, 1921, in Berlin, the interim agreement on the renewal of trade and economic cooperation between RSFSR and Germany was signed. The special role in the Soviet-German relations played the Rappalsky contract from 1922 which restored the diplomatic and consular relations between Russia and Germany. In the early twenties as a result of the activation of the Soviet-German relations a significant amount of the German engineers arrived in the Soviet Russia for work on industrial and other facilities. Within diplomatic relations between the countries the German consulates were opened in Leningrad, Tiflis, Novosibirsk, Vladivostok and also Kharkiv, Odesa and Kyiv. It should be noted that the activity of representatives of diplomatic services, the German engineers, representatives of commercial firms and other citizens of Germany which were in the country and also their possible contacts with inhabitants of the German colonies were monitored by intelligence agencies of the mode. It is important that existence of honeycombs of thousands of ethnic Germans living in the German and Mennonite colonies of the country was considered by the State Political Directorate as the base for implementation of large-scale intelligence and anti-Soviet activities from Germany is possible. In the circular letter of OGPU USSR No. 7/37 "On the German intelligence and fight against it" (on July 9, 1924) behind signatures of the vice-chairman of OGPU USSR G. Berries and the chief of counter prospecting department of OGPU A. Artuzov, it was noted: "After the conclusion of the Rappalsky contract, the German industry and trade had an opportunity to develop the activity in the territory of our republic. A huge influx of German businessmen concessionaires, industrialists and any businessmen who establish the commerce and industry enterprises, transport associations, tourist offices

\footnotetext{
3 Этноконфессия в советском государстве. Меннониты Сибири в 1920-1930-е годы: эмиграция и репрессии. Документы и материалы / [составитель и научный редактор А. И. Савин] / Андрей Іванович Савин. - Новосибирск: «Посох», 2009. - 752 с.

4 Этноконфессия в советском государстве. Вказана праця. - С. 8.
} 
and concessions are from this point observed" $"$. In the document, it was claimed: "The vast majority of these enterprises are engaged in investigation. Quite often these enterprises and any offices are exclusively prospecting bureaus for which the sign and usually exaggerated commercial combinations it is necessary masking" $"$. Let's pay attention that as it was emphasized in the circular of OGPU, "the multimillion population of the German origin is the soil for the German intelligence in Russia (kulak and "intellectual" elements it is mute colonies in villages and the cities), which is the main source of receiving and collecting by the German intelligence of data, on what from Germans special attention is paid"7. As the centers of intelligence activities the organizations of the German Red Cross and also the unions of the German colonists or as they were called in the document, "kulturfereyna" were called.

In another document known as the research opinion counter prospecting department of OGPU "The German Counter-revolutionary Work in the USSR" (no later than July 14, 1925) it was also talked of participation of the German population in implementation of Counterrevolutionary and intelligence activities for the benefit of Germany. The research opinion, as well as the circular letter of July 9, 1924, was developed with the assistance of the head of control and auditing department [counter-prospecting department - author] by A. Artuzov's OGPU. Let's pay attention that in the research opinion considerable attention is paid to the analysis of the situation in the German colonies of Ukraine. A. Artuzov noted: "Inspection, the carried-out KRO [counterprospecting department - author] OGPU at the end of 1924 in Ukraine, Youzhny East, and the Volga region yielded the following results: in Ukraine more than 300 German colonies, numbering more than 100.000 souls [the number not exact because on materials of a population census 1926 nearly 400,000 citizens of the German nationality lived in Ukraine], organized in various colonists unions are given. Accounting of Germans till.

Showed to Kharkiv what from the available three hundred Germans the unemployed is not present, - each of them holds a good position. They so strongly sat down at our industry, in some industries have it in the hands of the management. Among themselves, Germans represent the

\footnotetext{
5 Этноконфессия в советском государстве. Вказана праця. - С. 123.

6 Этноконфессия в советском государстве. Вказана праця. - С. 123.

7 Этноконфессия в советском государстве. Вказана праця. - С. 124.
} 
special national group which is directly connected with colonies" Analyzing a condition of the German colonies in Ukraine A. Artuzov noted that a considerable part of the German population is located in Ekaterinoslavsky and Odesa provinces. Rather German colonies of the Odessa province in the document it was noted: "The German colonists located in all territory of the province, but especially along the Romanian border. The number exceeds them colonists of the Ekaterinoslavsky province. In Odesa the German consulate was the ideological center of national and anti-Soviet work among Germans, extending the influence and on the Ekaterinoslavsky province, to the southern coast of the Black Sea to Novorossiysk, including the Crimea". Apparently, from the provided document, a special attention to the staff of the counter prospecting department of GPU inGerman colonies of the Odesa province was explained by the fact that they were disposed of close to Bessarabia and the Romanian border which was considered as strategically important in the military and political relation. Besides a part of the German colonies of the Ekaterinoslavsky province was in another strategically important region - the Crimea and the southern coast of the Black Sea. According to the logic of GPU they, residents of the German regions of a borderland, could become an object of influence of the German and Romanian intelligence and participate in the Counter-revolutionary and anti-Soviet activity. In the conclusions, the counter-prospecting department of OGPU claimed: "1. Germans inhabit large industrial districts, a border area and strategically important areas and salutary [so in the document - author] Agricultural areas.

The German colonists were a special category of the kulaks. [so in the document - author]. Religious and cultural features made them be hostilely to communism and the Soviet power. The German colonies were base of an anti-Soviet policy of Germans and policy of blasting from within". And further: "All German colonies and their heads are widely used as an information, and in case of war - harmful base"

These documents demonstrate that from the middle of the 1920th years, long before mass repressions at the time of "Big terror" of 19371938, the German population of the country was considered by intelligence agencies of the mode as base for expansion of mass anti-

\footnotetext{
8 Этноконфессия в советском государстве. Вказана праця. - С. 153.

9 Этноконфессия в советском государстве. Вказана праця. - С. 155.

10 Этноконфессия в советском государстве. Вказана праця. - С. 156.
} 
Soviet, nationalist and monarchic promotion and also implementation of intelligence activities for the benefit of Germany and other foreign countries. Statements about the German, Polish and other "nationalists" and "fascists" became a signal for the strengthening of a chauvinistic campaign in which first echelons there were Soviet and party leaders of the republic. The politburo, Organizational Bureau and the Secretariat of the Central Committee of RC (b) were accepted by tens of resolutions based on which were purged, and then and liquidation of educational institutions which carried out work languages of ethnic minorities. On April 19, ased1934 the Organizational Bureau of the Central Committee of $\mathrm{RC}(\mathrm{b})$ at made the decision "On implementation of the resolution of a November Plenum of the Central Committee and TsKK of RC (b) Wu Yi of the Politburo of the Central Committee of RC (b) at of 13.12.1933. "About a personnel of schools of ethnic minorities" in which it was noted that "regional party committees, especially Kyiv and Vinnytsia... did not understand what place in plans of counterrevolutionary work of the enemy in Ukraine is taken by a rate on education at the Polish and German schools of the younger generation in anti-Soviet spirit, and from here and organized arrangement by the enemy of the shots - the teachers managing schools, students of teacher's colleges, teachers opedagogical educational institutions" "In this regard the Central Committee of RC (b) at suggested to carry out on areas "a comprehensive inspection of all Polish and German schools, to look at shots of teachers and managers of these schools, shots of Pioneer leaders, to check a condition of teaching at these schools of social science, history and geography and to look at book fund of school libraries" "12. Implementation of checks was assigned to the special commissions for which the task was set "to reconsider the area behind the area, school behind the school" and in case of establishment of "the contamination facts" of schools "anti-Soviet elements" to take concrete measures" "13. It is clear, that among these actions there could be dismissals, arrests and other actions on "enemies of the people" and "antiSoviet elements".

On April 7, 1935 the Secretariat of the Central Committee of RC (b) at adopted the resolution "About Contamination Class and Hostile Elements of Hortitsky German Machine-building Technical School" in

\footnotetext{
${ }^{11}$ ЦДАГО України, ф. 1, оп. 7, спр. 375, арк. 36.

12 ЦДАГО України, ф. 1, оп. 7, спр. 375, арк. 36.

${ }^{13}$ ЦДАГО України, ф. 1, оп. 7, спр. 375, арк. 36.
} 
which it was noted that "as a result of full or inattention of a gorpartkom" [Hortitsky city party committee - author] To work of technical school its teaching and student's structure was "weed class and hostile elements which with impunity [so in the document - Buses] carried out in technical school for a long-time fascist promotion"14. It is important that criteria should take place according to closing of Hortitsky technical school. The secretariat of the Central Committee at instructed RC (b): "In view of the fact that in existence of special German technical school in Hortitsa there is no need and also considering that the technical school is not provided with educational structure at all, rooms and laboratories, - technical school to liquidate"

In this regard the Central Committee of $\mathrm{RC}(\mathrm{b})$ at obliged the Dnipropetrovsk regional committee of the party "after fixed of check of student's structure place students of this technical school" in other machine-building technical schools of the area ${ }^{16 .}$. In this document it was emphasized that there was not the cause of elimination "fascist promotion" and "contamination class and hostile elements". The fact that in its existence "there is no need".

Sharper charges in "class and hostile elements" which allegedly worked in national educational institutions contained in the resolution of the Politburo of the Central Committee of RC (b) at "About the Odessa German teacher training college" (on December 4, 1937) in which it is groundless was claimed: "By check it is established that the institute is incredibly littered by class and hostile people. So, for example, by the number of 254 students in the 89th relatives are arrested as enemies of the people, from teachers 4 fascists are exposed and arrested who worked for Bolsheviks and cadets are expelled from the Party. As a result of big contamination hostile elements at all of the unsatisfactory Party and mass work, at institute enemies nationalists, fascists built to themselves a nest, extended fascist literature there and carried out counter-revolutionary work" 17. In another document "The Report. Results of the inspection of the Odessa German teacher's college" (on December 4, 1937), it was also talked of "fascist" activity of ethnic Germans in an educational institution. These ridiculous charges became "reason" of cleaning student's and

\footnotetext{
${ }^{14}$ ЦДАГО України, ф. 1, оп. 7, спр. 382, арк. 125.

15 ЦДАГО України, ф. 1, оп. 7, спр. 382, арк. 125.

${ }^{16}$ ЦДАГО України, ф. 1, оп. 7, спр. 382, арк. 125.

${ }^{17}$ ЦДАГО України, ф. 1, оп. 7, спр. 382, арк. 125.
} 
teachers of the institute. "Enemies of the people" were exposed discharged from office, and part of them was repressed.

The German educational institutions based on other resolutions of "forbidden" characters were closed. Among them there was the resolution of the Politburo of the Central Committee of RC (b) at "Reorganization of national schools in Ukraine" (on April 10, 1938) ${ }^{18}$ and "Reorganization of special national schools, technical schools, the Odesa German teacher training college and special national departments and classes at schools, technical schools and higher education institutions of USSR" (on July 7, 1938) ${ }^{19}$ based on which national educational institutions were disbanded, or were translated into Ukrainian or Russian of training. Along with the liquidation of national educational institutions and other culturaleducational institutions reorganization of national administrative and territorial units was carried out. As it was stated above, instructions on carrying out reorganization and any punitive actions arrived from Moscow. On December 9, 1934, the Politburo of the Central Committee of RC (b) at adopted the resolution "About the German Areas (the Telegram of the Central Committee of the All-Union Communist Party (Bolsheviks) No. 513sh)". In the document it was noted: "The Soviet power will not suffer any attempts of the anti-Soviet activity or propaganda and will not stop refusing a residence right in the USSR or will send all persons, treat disloyally the Soviet power, to the remote places of the USSR" 20 .

In fact in this resolution the mainline of power structures on German and the Polish population as mass cleanings and other punitive actions were defined before deportation for "to the remote places of the USSR". Disbandment of national areas and village councils became one more of fight "forms" from "anti-Soviet" activity. On August 17, 1935, the Politburo of the Central Committee of RC (b) at adopted the resolution "About Markhlevsky and Pulinsky Rayni" [Pulinsky - the German national area] based on which these national administrative and territorial units which were in Kyiv region were disbanded. Such decision was explained to them by "economic weakness", "inconvenience of service of MTS of collective farms" and also "an administrative strip farming" 21.

\footnotetext{
${ }^{18}$ ЦДАГО України, ф. 1, оп. 6, спр. 463, арк. 2-3.

${ }^{19}$ ЦДАГО України, ф. 1, оп. 6, спр. 465, арк. 9.

${ }^{20}$ ЦДАГО України, ф. 1, оп. 16, спр. 11, арк. 294, 295.

${ }^{21}$ ЦДАГО України, ф. 1, оп. 6, спр. 375, арк. 132.
} 
Final disbandment of national administrative and territorial units happened to be in 1938-1939. The politburo of the Central Committee of $\mathrm{RC}$ (b) at adopted two resolutions on this matter: "About reorganization of national areas and the Village Councils of USSR to ordinary areas and the Village Councils" (on February 16, 1938) ${ }^{22}$ and "About elimination and transformations of artificially educated national areas and the Village Councils" (on April 7, 1939) ${ }^{23}$ based on which national areas were disbanded, and the Village Council were transferred to other areas of the republic. It should be noted that reorganization was carried out without due differentiations, however, and during administrative-territorial changes of 1938-1939. The defined "national policy" was traced, namely dispersion of ethnic minorities among the Ukrainian or Russian population. Formation of the reorganized areas happened to be as a part of their population as Germans, Poles, Bulgarians, as well as other national groups, made minority, or, at least, had no essential superiority in strength.

Since 1933 and also later - in 1935-1937 with liquidation of institutes of national and cultural development arrests and exiles of those who were connected to the forged case of the "counter-revolutionary" and "nationalist" organizations continued. The mass character was gained by deportations of ethnic minorities from places of their historical residence in Ukraine. As well as in previous years, repressive actions were followed by an intensive promotional campaign. A Soviet asset of the party, "propagandists" with maniacal persistence tried to create an image of "enemy" from People's Commissariat for Internal Affairs. On meetings and meetings, from stands of party forums appeals to punishment of German and Polish "fascists" sounded. "In Ukraine, we, first of all, meet fascism Polish and German", - with full knowledge of business V. Balitskii on a January (1936) Plenum of the Central Committee of RC (b) $\mathrm{at}^{24 .}$ The similar position on "fascist activity" of ethnic Germans expressed also at the XIII Congress of RC (b) at (May - June 1937). And at a congress, it was talked already not only of "fascist" and "nationalist" activity, and about "wrecking of various nations".

The further works which are carried out Ukrainian by the department of Soyuzneft and Ukrgeologtrest on the investigation of industrial oil

\footnotetext{
${ }^{22}$ ЦДАГО України, ф. 1, оп. 6, спр. 462, арк. 55, 62-65.

${ }^{23}$ ЦДАГО України, ф. 1, оп. 6, спр. 509, арк. 18, 81-84.

${ }^{24}$ ЦДАГО України, ф. 1, оп. 1, спр. 472, арк. 69.
} 
cannot be considered as satisfactory and with a quite simple reason. Of course, "wrecking of various nations" could not disregard, without a fight of such an episode of the transformation of Ukraine. Wrecking went from the very beginning" 25 Statements about "wrecking" Stalin henchmen tried to impose public consciousness idea that Germans, Poles, and representatives of other ethnic groups are potential traitors, spies, saboteurs whose harmful activity should be eradicated in any way.

Certain concrete measures which forms of application depended not so much on the availability of the collected "the compromising material", how many on imagination, to be exact a whim of off-takers of repressions became the "logical" investigation of such social mental set concerning Germans and Poles also. As it was stated above, the range of repressive actions was huge. There were actions of dismissal from work of people in connection with their national identity to arrests of members of the nonexistent counter-revolutionary organizations and deportations from the places of residence. Certain concrete measures which forms of application depended not so much on the availability of the collected "the compromising material", how many on imagination, to be exact a whim of off-takers of repressions became the "logical" investigation of such social mental set concerning Germans and Poles also.

Fabrication intelligence agencies of the mode of affairs of mythical Ukrainian, German, Polish and other fascist and nationalist organizations. The affairs of the espionage, diversionary and insurgent organizations consisting of Ukrainian, German, Polish, Greek and other "nationalists" were fabricated. And most the unions, organizations, the centers passing across the People's Commissariat for Internal Affairs line if existed, then only in the imagination of organizers of repressive actions. In 1930-1934 the State Political Directorate of USSR "exposed" a number of the "counter-revolutionary" organizations - "Union of Liberation of Ukraine" (SVU) "Ukrainian national center" and its structural division of "Ukrainian Military Organization" (UMO) "Block of the Ukrainian nationalist parties" (UKP, borotbist, Social Revolutionaries, esdek, etc.). It should be pointed out interesting characteristic detail as retaliatory bodies destroy "Ukrainian anti-Soviet" the organization In investigating it "becomes clear" that it is closely connected with "the international counter-revolution", first of all with the German and Polish fascism.

\footnotetext{
${ }^{25}$ ЦДАГО України, ф. 1, оп. 1, спр. 489, арк. 74.
} 
In 1937 People's Commissariat for Internal Affairs USSR "exposed" one more mythical espionage organization known as "The National Union of Germans in Ukraine". On March 16, 1937 Narkomat justices of the USSR sent to the secretary of the Central Committee of RC (b) at S. Kosior, the chairman of SNK USSR P. Lyubchenko and the People's commissar of justice of the USSR V. Krylenko "Spetsinformation" "About to counter-revolutionary] organization in the Hortitsky German college". In the document it was noted: "Special board of the Dnipropetrovsk regional court on February 19-22 of this year [y] $\mathrm{p}$ to [eye] are heard business of group of participants of the counterrevolutionary, fascist organization "The National Union of Germans in Ukraine" which organized the counter-revolutionary activity in Hortitsky German Pedagogical Technical school.It is established that the specified group was headed to [Olishna] by the director of the specified technical school Bilyk Martin and to [Olishna] the director of machine-building technical school Goyer"26. In Spetsinformation it was claimed that M. Bilyk received from "prospecting department" of the Berlin police of a problem of the following character:

"1. To develop in the territory of the Soviet Union work on the creation of the counterrevolutionary organizations from among the German population, having strengthened nationalist promotion among Germans.

2. To have a close connection with the German consulates in Odesa and Kharkiv, where to receive tasks on counter-revolutionary work.

3. To prepare shots for diversionary work from among members of the organization and in the first days of war of the Soviet Union with Germany - to pass to opened acts of sabotage (damages of page D. [Railway - author] Lines, bridges application of bacteria of infectious diseases, infection of water and t. other)"27.

Direct "counter-revolutionary" activity of "directors-wreckers" was that they artificially created heavy material living conditions (squandering of the food intended for students, etc.) in educational institutions, and then hired them in "the espionage organization".

Other concrete manifestations of "harmful" activity of the management of the technical school in "Spetsinformation" were not

${ }^{26}$ Німці в Україні. 20-30-ті pp. ХХ ст. [зб. док. держ. архівів України / упоряд.: Яковлева Л. В., Чирко Б. В., Пишко Л. П.]. - К.: НАН України, Ін-т історії України, 1994. - С. 191.

${ }^{27}$ Німці в Україні. 20-30-ті рр. ХХ ст. Вказана праця. - С. 192. 
given. For "spies", "saboteurs" and "counter-revolutionaries" who for many years allegedly acted for the benefit of the German prospecting bodies such practice looks somehow not serious and can raise only a smile. Another opinion there were those that were engaged in the business of "The National Union of Germans in Ukraine". From repressive bodies "wrecking" M. Bilyk, K. Goyera and other heads of "Union" was so dangerous to the Soviet power that they were made responsible separately "in the matter of the central administration of the counter-revolutionary organization". Rather ordinary participants of "the National Union" who generally were students in Spetsinformation it was noted: "... Only are accused of Yantsen, Kreft, Shteyninger, Dick, and Girsh knew about the final problems of a diversionary order of the organization which members they were. Other defendants did not know about these tasks because they were shown only the ropes of tasks inpeacetime".

"Considering this case, - proceeded further in the document, - the Special board considered that the main organizers and heads of this counter-revolutionary Union pass separately that from the defendants who are connected to this case nobody made concrete measures to the commission of acts of sabotage. The special board finds it possible not to apply to these enlisted persons to the highest measure, having limited to long imprisonment, in particular, Yantsen, Kreft, Geydik are sentenced to 10 years of imprisonment everyone in the remote places of the Union, Dick, Shteyninger, Girsh - for 7 (seven) years of imprisonment everyone, Groyman, Klassen, Kopp - for 6 (six) years of imprisonment everyone, Pauls, Vince and Schultz - for 5 (five) years of imprisonment everyone"28. Big "humanity" was shown by the power: 15 members of the organization for the fact that they "did not arrive" specific actions, were sentenced to imprisonment in "the remote places of the Union" for a period of 5 up to 10 years.

The tonality and the text of this document demonstrates to the artificiality of charges concerning the "espionage" activity of members of the organization and also that "business" was forged by retaliatory services of the mode. At the same time, scientists continued to research the questions connected with the business of this "espionage" organization.

\footnotetext{
${ }^{28}$ Німці в Україні. 20-30-ті рр. ХХ ст. Вказана праця. - С. 193-194.
} 
At the initiative of the author of the offered research the management of Institute of the National Relations and Political Science of NAN of Ukraine appealed to the Security Service of Ukraine to make the observations concerning objectivity of a sentence to participants of "The National Union of Germans in Ukraine" and also access the staff of institute with case papers of the specified organization.

By results of additional studying of case papers of "The National Union of Germans in Ukraine" to the Institute of the National Relations and Political Science of NAN of Ukraine, it was directed the answer. In the document, it was noted that the director of Hortitsky German machine-building technical school Karl Karlovic Goyer and the director of Hortitsky German pedagogical technical school Martin Gugovich Bilyk and also Yantsen Heinrich Petrovich, Klassen Heinrich Ivanovich, Shteyninger Nikolay Ottovich and other participants of "the counterrevolutionary fascist organization" were shot in August 1937 .

In June 1959 the Military Board of the Supreme Court of the USSR closed criminal case Goyer K. K., Bilyk M. G. and other "counterrevolutionaries" behind lack of evidence. On August 3, 1962, the Zaporizhia regional court was rehabilitated by Yantsen G.P., Klassen G.I., Shteyningera N.A. and also other participants of "Union". In the resolution of Presidium of the Zaporizhia regional court of August 3, 1962, on rehabilitation of the persons of the German nationality repressed in 1937 it was noted: "By additional check it is established that in business there are no proofs of anti-Soviet activity of the persons stated above, and case papers concerning them, in fact, it is fabricated. In the judicial session, a part of the defendants refused the indications, and in writs of appeal referred to application concerning the illegal methods of investigation" 29 . In the judicial session, a part of the defendants refused the indications, and in writs of appeal referred to application concerning the illegal methods of investigation" 30 .

To sum it up we can say that $t$ Institute of the National Relations and Political Science of NAN of Ukraine the staff of Management of the Security Service of Ukraine across the Zaporozhye region wrote in the letter: "Considering stated we consider that the persons specified by you, it is impossible to consider members of "The national union of Germans

29 Чирко Б. В. Національні меншини в Україні (20-30 роки ХХ століття). - К.: Асоціація «Україно», 1995. - С. 209-210.

30 Чирко Б. В. Національні меншини в Україні . Вказана праця. - С. 209-210. 
to Ukraine" as it actually did not exist". As we see, the case of "The National Union of Germans in Ukraine" was framed up by retaliatory services of the mode. So, in August 1937 blood of innocent people was shed. There was no "espionage" activity, there was no "nationalist" promotion, there was no preparation for conducting biological warfare by "Union" in the territory of Ukraine. There was another fact that participants of nonexistent "Union" and those in which the Special board of the Dnipropetrovsk regional court was engaged and those which were connected to the case of the central administration and to which the capital punishment was applied were the repressed fault.

Summarizing told, it should be noted on materials of adjudications for "The union of liberation of Ukraine", "The Ukrainian military organization", "The Polish organization military", "The National Union of Germans in Ukraine" as well as other "espionage" and "nationalist" organizations hundreds of citizens of Ukraine - Ukrainian, Poles, Germans, Jews were repressed, it is groundless accused of subversive and anti-Soviet activities.

Naturally, there is a question of quantitative indices of victims of political repression as a result of the criminal activity of Stalin totalitarian regime.

Information on the matter adequately contains documents of the Public Records Office of the Security Service of Ukraine (Kiev) and also the Public Records Offices of the SSU on Donetsk, Zaporizhia and other areas. Characterizing quantitative indices of losses as a result of repressions we will note that in August 1937 - November 1938 of People's Commissariat for Internal Affairs of the USSR carried out largescale repressive actions which became known under the generalizing name "Big Terror" later" On number passed the greatest number of victims of political repression within the so-called "kulak operation" which was carried out in compliance with the order of People's Commissariat for Internal Affairs of the USSR for No. 00447 of July 30, $1937^{32 .}$ Along with it during the so-called "big cleaning" or "mass operation" of People's Commissariat for Internal Affairs of the USSR adopted also several orders on holding repressive actions to "counterrevolutionary" national groups. Operations concerning representatives of

\footnotetext{
31 Этноконфессия в советском государстве. Вказана праця. - С. 30.

32 Этноконфессия в советском государстве. Вказана праця. - С. 30.
} 
certain ethnic groups in documents of People's Commissariat for Internal Affairs were called "linear". For example - "the German line", "the Polish line", "Greek", "Romanian" so on.

On July 25, 1937 People's Commissariat for Internal Affairs of the USSR adopted order No. 00439 on the repressions concerning the German citizens suspected of espionage activity against the USSR; On August 11 the same year it was accepted operational order No. 00485 "About operation on the repression of members of "POV", prisoners of war of the Polesia army, deserters from Poland, political emigrants of Poland, the former members of PPS [Sets Polish socialist are - author] And other

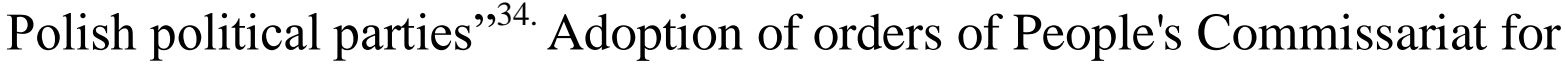
Internal Affairs on carrying out "linear operations" was usually preceded by the relevant decisions of the Politburo of the Central Committee of the All-Union Communist Party (bolsheviks) on July 20, 1937 the Politburo of the Central Committee of the All-Union Communist Party (bolsheviks) makes the decision on arrest of all Germans working at the defense enterprises; On August 9 1937bylo the decision of the Politburo of the Central Committee of the All-Union Communist Party (bolsheviks) on the adoption of the order of People's Commissariat for Internal Affairs of the USSR on elimination of the Polish diversionary and espionage groups and the organizations of the Polish organization military 35 .

It is important to pay attention to content of the special order of People's Commissariat for Internal Affairs on implementation of repressive actions "on the German line" which was not accepted. As A. Savin, in reports of UNKVD on Ukrainian areas where it was talked of carrying out all mass operations including on "national" lines, it was noted that within the operation to ethnic Germans (the "German" operation) of repression were carried out "as order No. 00485, that is the order on carrying out repressions with Poles, but not according to order 00439 notes $^{36}$. As for order No. 00439 of July 25, 1937, about operational accounting and arrest of all Germans who were not citizens of the USSR we will note, on V. Nikolsky's materials in 1937. Across Ukraine for "counter-revolutionary", "espionage" and other forms of "anti-Soviet" activity were repressed 159,632 persons, ethnic Germans made of them

\footnotetext{
33 Этноконфессия в советском государстве. Вказана праця. - С. 45.

34 Этноконфессия в советском государстве. Вказана праця. - С. 45.

35 Этноконфессия в советском государстве. Вказана праця. - С. 45.

36 Этноконфессия в советском государстве. Вказана праця. - С. 30.
} 
16,228 . The author concludes that as such number (nearly 20,000 people) of German foreigners in Ukraine could not be, the prevailing most of the victims of political repression retaliatory services of the mode was made by German citizens of the USSR. There was mass deportations of the German population from places of their traditional resettlement in Ukraine Mass Deportations of the German Population from the Places of their Traditional Settlement of Ukraine.

In 1937 mass punitive operations fell upon the German population of Odessa region in the territory of which 120,000 Germans at that time lived, from them 50,000 lived in three German national areas - Spartak, to Zeltsky and Karl-Libknekhtivsky. The Odessa regional committee of RC (b) at, "experts" from People's Commissariat for Internal Affairs claimed that the population of these areas is captured by "counterrevolutionary fascist activity". In this regard to the Central Committee of RC (b) at "The reference to the report on a political condition of the German areas of Odessa region" was directed (September 1937). In the "Reference" prepared by the staff of People's Commissariat for Internal Affairs it was noted: "... The German population of Ukraine is considered by fascist prospecting bodies as Wednesday from where force and an asset of its subversive activities in Soviet Ukraine undertakes". And further: "This circumstance is confirmed with all materials on caught by us fascist formations. It is enough to tell that since 1933, in these three areas it was (generally) exposed and liquidated 124 fascist, espionage diversionary and insurgent organizations. 6. Only for the last three months: June - August, in area 49 fascist, diversionary and insurgent organizations in which it is arrested more 800th persons [age], and from this quantity -580 after these three national areas are exposed"37. The fact that in three summer months 1937 a third of the "fascist" organizations in comparison with the previous four years was exposed draws attention. It is easy to find an explanation for it. Increase of intensity in the identification of various "counterrevolutionary" and "espionage" organizations for Odessa region happened after sadly February-March (1937) Plenum of the Central Committee of the All-Union Communist Party (Bolsheviks) which decision was led to a bacchanalia of repressions when the country was covered with the blood of the innocent victims. For providing bigger efficiency of People's Commissariat for Internal Affairs offered to repressions: "Without

\footnotetext{
${ }^{37}$ Німці в Україні. 20-30-ті рр. ХХ ст. Вказана праця. - С. 195.
} 
weakening expeditious blow of People's Commissariat for Internal Affairs to defeat of an underground in the German villages... to immediately develop party and mass work in the German areas; to strengthen the specific management through the Soviet work all these measures provided first of all expeditious blow". A separate point in the document set a task: "To move counter-revolutionary elements from the German districts of the area - up to 5,000 families..., ${ }^{38}$.

If to assume that each family consisted of 3-4 people, then provided People's Commissariat for Internal Affairs to move in 20000 Germans or every second resident of the German national areas of Odessa region.

That's no doubt that mass deportations of the German and Polish population from places of their traditional settlement officially were explained not only by participation in "counter-revolutionary" activity of "anti-Soviet" elements but also the reasons of economic and militarypolitical character, in particular introduction of measures for strengthening of a borderland. These measures first of all in strategically important regions to which, as is well-known also Ukraine belonged were carried out. Such special attention of the Moscow authorities concerning Ukraine was defined also by scale of the resettlements which were carried out in its different areas including in a border strip. In 1935-1936. The politburo of the Central Committee of RC (b) it adopts a number of resolutions "About Resettlement from a Borderland of 8,300 Farms in connection with Defensive Reasons and about Resettlement to Border Areas 4,000 of the Best Collective Farmers of the Kiev and Chernihiv Regions" (on January 23, 1935) "39. "About resettlement of the Polish and German farms from a borderland" (on November 25, 1935) 40; "On resettlements to Kazakhstan (the Resolution of the Central Committee of the All-Union Communist Party (Bolsheviks) of 17.01.36.)" (on March 15, 1936) ${ }^{41}$; "About resettlement of 15,000 farms of the Kiev and Vinnytsia regions to Kazakhstan" (on April 9, 1936)" "About resettlement of inhabitants kilometer a borderland throughout frontier in Kiev region" (on August 7, 1936). On the basis of the specified documents tens of thousands of inhabitants of a border area, Ukrainian, Germans, Poles, as well as representatives of other ethnic groups, were moved in east and southern

\footnotetext{
${ }^{38}$ Німці в Україні. 20-30-ті рр. ХХ ст. Вказана праця. - С. 200.

${ }^{39}$ Свтух В. Б. Німці в Україні (1920-і-1990-і роки) / В. Б. Свтух, Б. В. Чирко. - К.: ІНТЕЛ, 1994. - С. 75.

${ }^{40}$ Свтух В. Б. Німці в Україні (1920-і-1990-і роки) / В. Б. Євтух, Б. В. Чирко. - К.: ІНТЕЛ, 1994. - С. 76.

${ }^{41}$ Свтух В. Б. Німці в Україні (1920-і-1990-і роки) / В. Б. Євтух, Б. В. Чирко. - К.: ІНТЕЛ, 1994. - С. 77.
} 
parts of the republic (Kharkiv, Donetsk, Dnipropetrovsk, southern частик Kiev region) and also "out of borders of Ukraine", in particular, Kazakhstan.

Later also those German colonists who lived in the territory of Western Ukraine were subject to deportations. It is known that according to the Soviet-German contract of August 28, 1939 (Molotov-Ribbentrop Pact) there was a division of "spheres of influence" of the USSR and Germany in Eastern Europe. Under the observation of the mixed SovietGerman commission, most of the German population living in the West Ukrainian lands moved to Germany or zones of its influence. Those Germans who wanted to leave to new areas of the Soviet Union but were not accepted by the German authorities were sent to eastern regions of the country. In this regard it should be emphasized that Germans, Poles, as well as representatives of some other ethnic groups were considered by authorities of Ukraine as "the harmful nations". It is clear, that a similar relation was also concerning ethnic Germans who appeared in zones of control of the Soviet Union. Moreover, Germans, lived in the territory of Poland dismembered in September 1939 by the totalitarian modes earlier were considered by the Soviet power not only as "the German population", but also as the former citizens of the country, belonged to "bourgeois", the "imperialistic" world. Similar "circumstances" caused in representatives of the Soviet and party device, People's Commissariat for Internal Affairs and other government institutions special attention, concern, and aspiration in any stop methods possible, hypothetically representations a possibility of implementation from ethnic Germans of "anti-Soviet" and "espionage" activity. As a result concerning this category of citizens of the German nationality, as well as in general to the German population of the country, mass arrests, deportations and other forms of repressive actions continued to be carried out. Moreover, Germans, lived in the territory of Poland dismembered in September 1939 by the totalitarian modes earlier were considered by the Soviet power not only as "the German population", but also as the former citizens of the country, belonged to "bourgeois", the "imperialistic" world. Similar "circumstances" caused in representatives of the Soviet and party device, People's Commissariat for Internal Affairs and other government institutions special attention, concern, and aspiration in any stop methods possible, hypothetically representations a possibility of implementation 
from ethnic Germans of "anti-Soviet" and "espionage" activity. As a result of the study it was possible to come to a blind conclusion that in the late twenties, Stalin totalitarian regime was finally created. Cardinal changes happened to be in the field of national policy - the Ukrainisation began to be displaced, state policy on ethnic minorities was changed. A special scope acquires repressive shares on "nationalists" and "fascists" including from the circle of ethnic minorities. Prosecution of "nationalists" and "fascists" was caused and closely connected with administrative and imperative methods of implementation of domestic policy, strengthening of the repressive policy of the totalitarian regime. Repressions concerning "nationalists" (German, Polish others) were connected also with the international factor - aggravation of the situation in the world. Deterioration in the relations of the USSR with Germany and Poland and the corresponding strengthening of the anti-German and antiPolish promotional campaigns caused, in particular, a special bias of the Soviet power structures concerning German and the Polish population, was considered to be as a potential base of "fascist" activity in the country. However purposeful promotional campaigns and repressive actions of retaliatory bodies of the mode in which aim objects were ethnic Germans in the USSR began aggravation of the Soviet-German relations in the early thirties much earlier.

On the basis of found and investigated archival documents foreign and domestic researchers came to a conclusion that else long before arrival in Germany to the power of Nazis and also emergence of military danger, the management of the Soviet intelligence agencies began to form the concept of the German diaspora as "espionage and diversionary" bases in the USSR. Documents convincingly demonstrate it. They cover the participation of the management of OGPU in the mid-twenties. It should be pointed out the next documents to have been studied as "Circular letter of OGPU USSR No. 7/37 "On the German intelligence and fight against it" and "Reference counter prospecting department of OGPU "The German Counterrevolutionary Work in the USSR".

In the forefront of a chauvinistic campaign being orientated against the German, Polish "nationalists" and "fascists" there were Soviet and Party leaders of the Republic. The politburo, Organizational Bureau and the Secretariat of the Central Committee of RC (b) were accepted by tens of resolutions based on which were purged, and then liquidation of 
educational institutions that carried out work languages of ethnic minorities. Along with the liquidation of national educational institutions and cultural-educational institutions reorganization of the German and other national administrative and territorial units were carried out. Moreover, the Soviet and Party leadership of Ukraine began to consider certain ethnic communities, first of all, Germans and Poles as representatives of "the harmful nations".

Large-scale punitive actions which range of application was huge became the investigation of such social mental set in relation to Germans and Poles. There were different forms as dismissal of people from work for their ethnic origin to arrests of members nonexistent "counterrevolutionary" and "the espionage organizations and also mass deportations of the German and Polish population from places of their traditional accommodation.

\section{CONCLUSIONS}

In the late twenties, Stalin totalitarian regime was finally created. Cardinal changes happened to be in the field of national policy. The "Ukrainisation" began to be displaced. A state policy on ethnic minorities was changed too. A special scope acquired repressive shares on "nationalists" and "fascists" including from the circle of ethnic minorities. The prosecution of "nationalists" and "fascists" was caused and closely connected with administrative and imperative methods of implementation of domestic policy, strengthening of the repressive policy of the totalitarian regime.

Repressions concerning "nationalists" (German, Polish and others) were connected with the international factor. It was an aggravation of the situation in the world. Deterioration in the relations of the USSR with Germany and Poland and the corresponding strengthening of the antiGerman and anti-Polish promotional campaigns caused, in particular, a special bias of the Soviet power structures with German and the Polish population. It was considered as a potential base of "fascist" activity in the country. However purposeful promotional campaigns and repressive actions of retaliatory bodies of the mode in which aim objects were ethnic Germans in the USSR began aggravation of the Soviet-German relations in the early thirties much earlier. 
On the basis of archival documents which recently have been found by foreign and domestic researchers it was possible to conclude that else long before arrival to the power of Nazis and also emergence of military danger in Germany the management of the Soviet intelligence agencies began to form the concept of the German diaspora as "espionage and diversionary" bases in the USSR. Documents convincingly demonstrate it. They cover the participation of the management of OGPU in the midtwenties. It should be pointed out the next documents to have been studied as "Circular letter of OGPU USSR No. 7/37 "On the German intelligence and fight against it" and "Reference counter prospecting department of OGPU "The German Counterrevolutionary Work in the USSR". They testify to main results represented scientific study.

In the in the forefront of a chauvinistic campaign being orientated against the German, Polish "nationalists" and "fascists" there were Soviet and party leaders of the Republic. The politburo, Organizational Bureau and the Secretariat of the Central Committee of RC (b) were accepted by tens of resolutions based on which were purged, and then a liquidation of educational institutions which carried out work languages of ethnic minorities. Along with the liquidation of national educational institutions and cultural-educational institutions reorganization of the German and other national administrative and territorial units were carried out.

Moreover the Soviet and party leadership of Ukraine began to consider certain ethnic communities, first of all, Germans and Poles as representatives of "the harmful nations". Large-scale punitive actions which range of application was huge became the investigation of such social mental set in relation to Germans and Poles: from dismissal of people from work for their ethnic origin to arrests of members nonexistent "counter-revolutionary" and "the espionage organizations and also mass deportations of the German and Polish population from places of their traditional accommodation.

A special attention should be paid to the results of the Stalin mode repressions (mass deportations, etc.) So the number of repressed German ethnic minority was reduced with 395,000 (by results of a population census in 1926) to 37,000 people (for 1987). Essentially what was in Ukraine in the 1920th - the 1930th. is genocide.

In this regard it should be noted that the International convention of 1948 "Prevention of Genocide and Punishment for it" defined genocide as 
actions that are committed to the destruction in whole or in part of any national, racial or religious group, including extermination of members of such group, drawing heavy bodily harms by it, deliberately formations of the vital conditions calculated on their full or partial physical destruction.

Without exaggeration, it is possible to tell that repressive actions of the Stalin mode had the genocide form concerning the German ethnic group of Ukraine.

\section{SUMMARY}

In this regard it should be noted that the International convention of 1948 "Prevention of Genocide and Punishment for it" defined genocide as actions that are committed to the destruction in whole or in part of any national, racial or religious group, including extermination of members of such group, drawing heavy bodily harms by it, deliberately formations of the vital conditions calculated on their full or partial physical destruction.

Without exaggeration, it is possible to tell that repressive actions of the Stalin mode had the genocide form concerning the German ethnic group of Ukraine.

\section{REFERENCES}

1. Партробітник України. Орган Центрального комітету та Харківського обласного Комітету Комуністичної партії (більшовиків) України. - 1933. - № 16. - С. 35.

2. Этноконфессия в советском государстве. Меннониты Сибири в 1920-1930-е годы: эмиграция и репрессии. Документы и материалы / [составитель и научный редактор А. И. Савин] / Андрей Іванович Савин. - Новосибирск: «Посох», 2009. - 752 с.

3. Хмельников О. Г. Торговельні зв'язки як фактор становлення добросусідських відносин між Україною та Німеччиною на початку 1920-х років / Олександр Григор'євич Хмельников // Вопросы германской истории: [сб. науч. тр. / ред. кол.: С. И. Бобылева (отв. ред.) и др.]. - Дніпропетровськ: Вид-во Дніпропетровського ун-ту, 2001. - С. 223-224.

4. ЦДАГО України, ф. 1, оп. 7, спр. 375, арк. 36.

5. ЦДАГО України, ф. 1, оп. 7, спр. 382, арк. 125.

6. ЦДАГО України, ф. 1, оп. 6, спр. 459, арк. 135.

7. ЦДАГО України, ф. 1, оп. 6, спр. 463, арк. 2-3. 
8. ЦДАГО України, ф. 1, оп. 6, спр. 465, арк. 9.

9. ЦДАГО України, ф. 1, оп. 16, спр. 11, арк. 294, 295.

10. ЦДАГО України, ф. 1, оп. 6, спр. 375, арк. 132.

11. ЦДАГО України, ф. 1, оп. 6, спр. 462, арк. 55, 62-65.

12. ЦДАГО України, ф. 1, оп. 6, спр. 509, арк. 18, 81-84.

13. ЦДАГО України, ф. 1, оп. 1, спр. 472, арк. 69.

14. ЦДАГО України, ф. 1, оп. 1, спр. 489, арк. 74.

15. Німці в Україні. 20-30-ті рр. ХХ ст. [зб. док. держ. архівів України / упоряд.: Яковлева Л. В., Чирко Б. В., Пишко Л. П.]. - К.: НАН України, Ін-т історії України, 1994.- 243 с.

16. Чирко Б. В. Національні меншини в Україні (20-30 роки ХХ століття). - К.: Асоціація «Україно», 1995. - 215 с.

17. Нікольський В. М. Репресії органів державної безпеки щодо німців України у 1937 році: кількісні показники / Володимир Миколайович Нікольський // Вопросы германской истории: [сб. науч. пр. / ред. кол.: С. Й. Бобилєва (відп. редактор) та ін.] Дніпропетровськ: Вид-во Дніпропетровського ун-ту, 2001. - С. 52-53. 18. Свтух В. Б. Німці в Україні (1920-і-1990-і роки) / В. Б. Свтух, Б. В. Чирко. - К.: ІНТЕЛ, 1994. - 183 с. - (Центр етносоц. та етнополіт. досліджень Ін-ту соціології НАН України).

\section{Information about the author:} Chirko B. V.

Candidate of Historical Sciences, Associate Professor of Philosophy and History of Educational and Scientific Humanitarian Institute of the

V. I. Vernadsky Taurida National University 